\title{
Blowing smoke: the history of tobacco-specific nitrosamines in Canadian tobacco
}

\author{
Neil Collishaw
}

- Additional material is published online only. To view please visit the journal online (http:// dx. doi. org/ 10.1136/ tobaccocontrol- 2015-052873).

\section{Correspondence to}

Neil Collishaw, Physicians for a Smoke-Free Canada, 134

Caroline Avenue, Ottawa, Ontario, Canada K1Y 0S9; ncollishaw@ smoke-free.ca

Received 8 December 2015 Accepted 13 May 2016 Published Online First 7 June 2016
CrossMark

To cite: Collishaw N.

Tob Control

2017;26:365-370.

\section{ABSTRACT}

Objective To demonstrate how changes in tobacco flue-curing practices in the 20th century increased levels of tobacco-specific nitrosamines (TSNAs) in tobacco smoke.

Methods Previously undisclosed documents and testimony made public as a result of a class action trial against tobacco companies in Montreal, Canada, were reviewed for information on TSNAs and tobacco curing practices. These were combined with other pertinent documents to form the basis for a comprehensive historical review of TSNAs and tobacco curing practices.

Results In the 1960s and 1970s, a change was made from indirect heating to direct heating for flue-curing tobacco that resulted in an increase in the TSNA-to-tar ratio in flue-cured tobacco. This occurred in both Canada and the USA. When this change was made, tobacco companies did not monitor for increased levels of TSNAs and did not study possible adverse effects on human health. As a result, smokers were unknowingly exposed to unnecessarily high levels of TSNAs for 30-40 years. In recent years, tobacco companies have changed curing practices back to indirect heating, thus returning the TSNA-to-tar ratios in tobacco smoke to their previously low levels.

Conclusions In view of this information brought to light in this paper, any claims by tobacco companies that they were acting prudently by lowering TSNA levels are unwarranted. They fail to acknowledge that it was their actions that raised TSNA levels in the first place about half a century ago.

\section{INTRODUCTION}

In 1998, two class actions were launched in Montreal against the tobacco industry. One is in the name of Cécilia Létourneau on behalf of all addicted smokers of Quebec. The other case is in the name of the Conseil québécois sur le tabac et la santé and Jean-Yves Blais (Mr Blais, who suffered from lung cancer and chronic obstructive lung disease, passed away during the trial.). Judgement rendered on 27 May 2015 (a corrected version was issued on 9 June 2015) awarded the Blais plaintiffs \$C15.5 billion in damages, including interest. Punitive damages of \$C131 million were awarded in the Létourneau case, but no payout to individual class members was awarded. ${ }^{1}$ The decision by the court of first instance is under appeal.

Many of the documents that became public during the trial shed light on the changes in tobacco curing practices in Canada since the 1950s. During this period, Canadian tobacco curing practices have changed several times. ${ }^{i}$ These changes in curing practices resulted, first in an increase and then, decades later, a decrease in the levels of tobacco-specific nitrosamines (TSNAs) in tobacco smoke. TSNAs are among the most potent human carcinogens known. ${ }^{2}$

\section{METHODS}

The plaintiffs' database ${ }^{3}$ of testimony and exhibits were searched for all references to tobacco curing or TSNAs. Documents so identified formed the first source of information for this historical review and analysis. These documents are listed in online supplementary appendix tables S1.1 and S1.2. The documents were further scrutinised to identify those that would help describe changes in curing practices and related changes in levels of TSNAs. Various published and unpublished public documents were also invoked, including the Truth Tobacco Industry Documents online library, so that a comprehensive historical analysis of changes in tobacco curing practices and levels of TSNAs could be performed.

\section{RESULTS}

\section{Nitrosamines and TSNAs}

Nitrosamines are a large group of carcinogens that cause a wide range of tumours in many species of animals. Tobacco products are the largest source of exposure to these carcinogens. Ten carcinogenic nitrosamines have been identified in tobacco smoke. Four of these are in the subclass of TSNAs, frequently known by their acronyms of NNN, NNK, NAT and NAB. ${ }^{\text {ii }}$ As their name implies, these TSNAs occur only in tobacco smoke. NNN and NNK are the most studied of these TSNAs. They are powerful carcinogens and they are organ-specific. In animal studies, NNN causes tumours of the oesophagus and nasal cavity, while NNK targets the lungs. NNK is the only tobacco smoke carcinogen that causes lung tumours in all the three rodent species commonly used in laboratories-rats, mice and hamsters. ${ }^{2}$

${ }^{\mathrm{i}}$ The trial record contains more testimony and many more documents concerning tobacco-specific nitrosamines than are referenced in this paper. For those interested in exploring all of the testimony and evidence pertaining to tobacco-specific nitrosamines, a tabular summary of this material has been prepared and is shown in online supplementary appendix tables S1.1 and S1.2.

${ }^{i i}$ NNN, N-nitrosonornicotine; NNK, 4-(methylnitrosamino)1-(3-pyridyl)-1-butanone; NAT, N'-nitrosoanatabine; NAB, $\mathrm{N}$-nitrosoanabasine. The acronym NNK is derived from an earlier chemical name for the same substance$\mathrm{N}$-nitrosamino NorKetone. 
Nitrosamines were first identified as carcinogens in 1956. By 1964, NNN had been identified as a possible constituent of tobacco smoke. During the 1960 s and 1970 s, tobacco company scientists followed scientific developments concerning nitrosamines and conducted research of their own that confirmed the presence in tobacco smoke of nitrosamines. By 1974, TSNAs had been definitively identified in tobacco smoke. ${ }^{4}$

It was known by the 1970s that TSNAs were formed during tobacco curing processes. TSNAs can be produced by a variety of chemical reactions. One of the principal ways that TSNAs are produced is through the incomplete combustion of propane or natural gas fuels used for curing yields oxides of nitrogen; oxides of nitrogen react with nicotine to produce TSNAs. ${ }^{5}$

Despite this knowledge, it would not be until the 21st century that any steps were taken by the tobacco industry to reduce levels of nitrosamines and TSNAs in tobacco smoke. In 1982, an RJ Reynolds scientist stated 'Tobacco scientists have demonstrated that both volatile and tobacco specific nitrosamines are related to nitrate levels in the tobacco', and, 'We have developed no procedures to control either nitrates or nitrosamine levels in our products'. ${ }^{6}$

\section{Early tobacco curing practices in Canada}

Until the 1960s, tobacco was cured by indirect heating through stovepipes or flues. A wood, oil, gas or coal-fired furnace was inside the curing barn. The furnace flue, however, did not take the shortest route to be exhausted to the outside. Instead, there was a very long flue that snaked throughout the barn before being exhausted to the outside. The flue gave off a gentle indirect heat that cured the tobacco-hence the name-'flue-cured tobacco'. The dirty black smoke never came in contact with the curing tobacco. Figure 1 shows a flue-curing barn in operation, belching black coal smoke out of the flue exhaust. ${ }^{7}$ Figure $2^{8}$ shows the flue snaking around the legs of a cure man.

In the 1960s and 1970s, there was general enthusiasm for improving energy efficiency. In the tobacco industry, improving curing techniques achieved several objectives-reducing environmental pollution, reducing costs and improving uniformity of tobacco curing. Several changes that achieved these objectives were introduced sequentially from the 1960s to the 1980s. All involved the abandonment of flues for flue curing and exposing the curing tobacco directly to exhaust gases from natural gas or propane fires. By the 1970 s, there was neither more use of flues nor any other form of indirect heating to flue-cure tobacco. Since that time, 'flue-cured' has persisted as an anachronistic misnomer. Existing flue-curing barns were converted first to barns with open gas burners placed on the floor of the barn. Later, they were converted to downdraught kilns, as shown in figure $3 .^{9}$

In a downdraught kiln the burner was placed outside the barn. The exhaust gases from the natural gas or propane burner rose through the metal construction seen in figure 3 . These exhaust gases were then pulled back into the barn at the top and distributed along the length of the barn by a horizontal-facing fan. Then the gases were forced downwards over the tobacco by a series of downdraught fans hung from the ridge of the barn. The cooling fumes were then exhausted near ground level. This produced a more even heat throughout the barn than the system of open burners on the floor of the barn. Finally, the old-style kilns were entirely abandoned in favour of bulk kilns.

All these newer curing systems blew combustion gases directly on to the tobacco. ${ }^{10}$ Efficiency, cost reduction, uniformity of curing and cigarette taste were all taken onto consideration as these changes in curing techniques were introduced. Yet it was

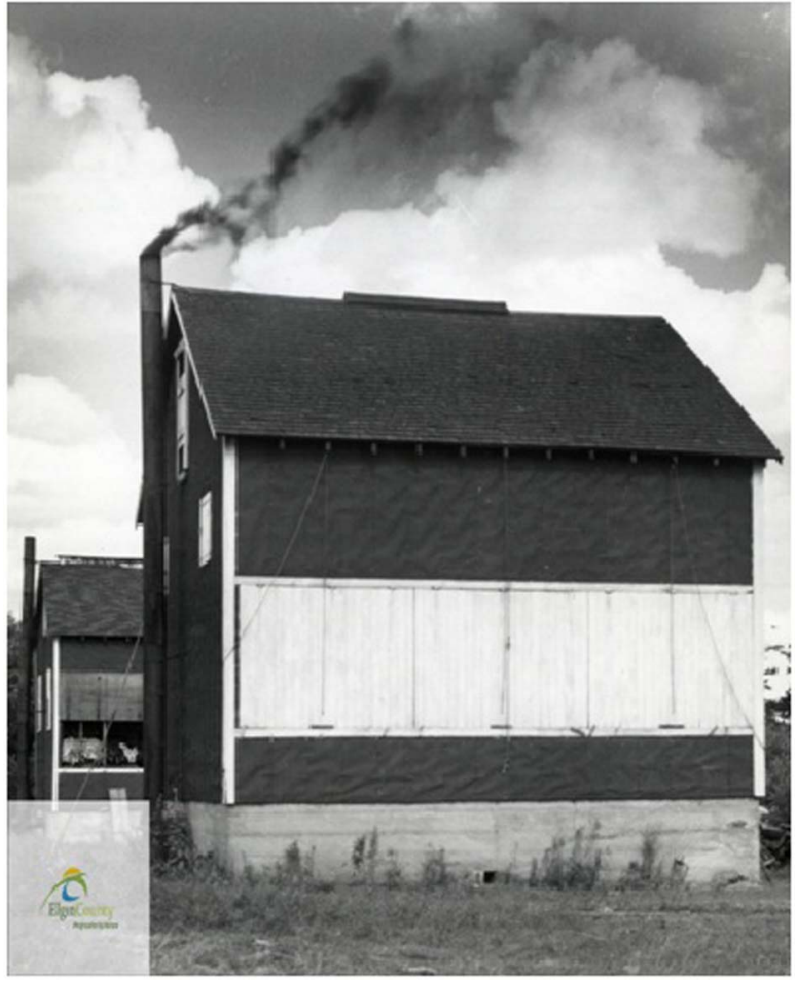

Figure 1 Coal-fired kiln.

known in the 1970s that a set of potent carcinogens-(TSNAs) -were formed during the curing process. The 1979 US Surgeon General's report stated:

During curing and fermentation of TSNAs can be formed....

There is no evidence that anyone, either inside the tobacco industry or elsewhere ever checked to see if blowing the products of combustion onto curing tobacco might pose an additional hazard to human health.

Steven Chapman was an analytical chemist who began working for Rothmans, Benson and Hedges when he was in his 30s. Mr Chapman was one of the younger witnesses to testify. His main areas of responsibility were cigarette emissions testing and reporting. His position at the time of his testimony was Manager for Product Development for Canada. However, as the company's designated witness on a wide range of topics, he had reviewed documents pertaining to many areas of the company's operations. ${ }^{11} \mathrm{He}$ would only have learned about the history of curing practices through reading documents and talking to older colleagues. His learning in this area was thus incomplete. On 23 October 2013, Rothmans Benson and Hedges witness for the defendants, Steven Chapman, mistakenly reported:

...to my knowledge, it's never been done...not never, but as far as I know about going back in history, it was always done by direct curing. ${ }^{12}$

However, the relatively young Mr Chapman's knowledge did not extend back to the 1970s and earlier. At that time indirect heating through flue curing predominated. ${ }^{10}$ To explain in detail tobacco companies' recent actions to lower levels of TSNAs, the defendants called on Dr Jeffery Gentry from the USA. He is Executive Vice-President of Operations and Chief Scientific Officer for RJ Reynolds. ${ }^{13}$ Dr Gentry was part of the team that first identified direct fire curing as a source of increased levels of 
Figure 2 A cure man working in a kiln. The flue snakes around his legs.

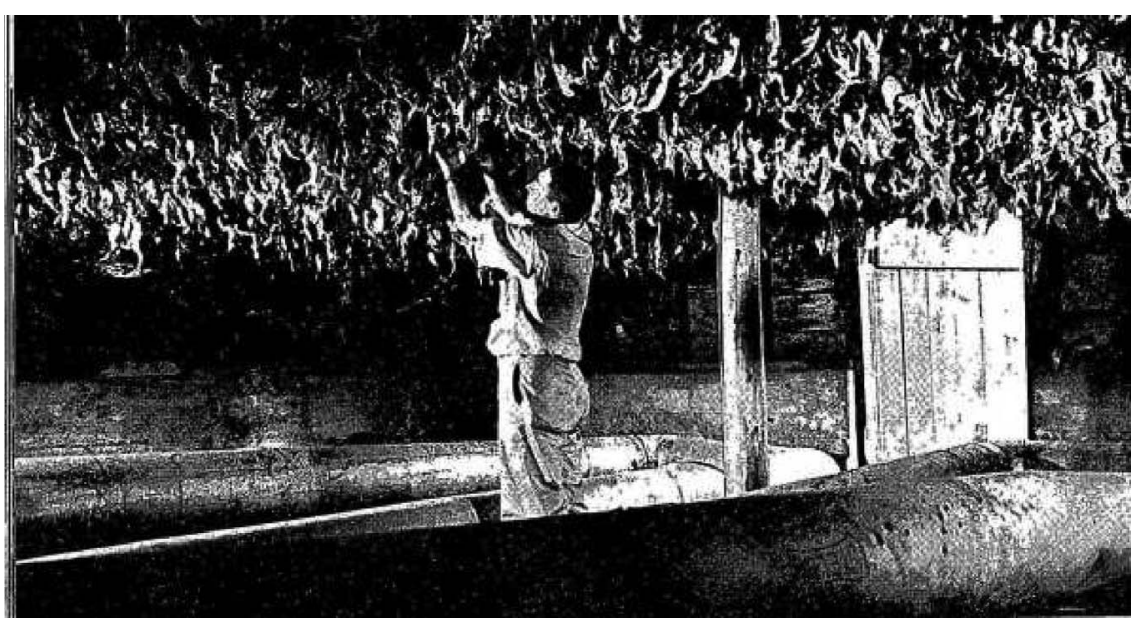

TSNAs in cigarettes. ${ }^{14}$ While the link between direct fire curing and increased levels of TSNAs was first established in 1999, Dr Gentry, nevertheless, confirmed that it had been well known for a long time that natural gas combustion would produce oxides of nitrogen, and that TSNAs could be formed in an environment rich in nicotine and oxides of nitrogen.

Q-But the fact that natural gas produces nitric oxides is not new, it has been known for a very long time; right?

A-I think that that's been known for quite a while.... ${ }^{15}$

Despite having this knowledge since the 1970 s, tobacco scientists in Canada did not check combustion gases as a possible source of oxides of nitrogen until 2000.

While no tests for nitrosamines under different curing regimes were done when these curing regimes were introduced in the 1960 s and 1970 s, it is possible to confirm that nitrosamine levels were low in flue-cured tobacco that was cured indirectly through flues. Gentry and his coworkers in a 1999 report found six barns that still used indirect heating through old-style flue curing. The nitrosamine levels in tobacco from these barns was as low or lower than tobacco cured by the modern method of indirect heating using heat exchangers, and 20-40 times lower than the TSNA levels in tobacco cured in direct-fired kilns as shown in table $1 .^{14}$

Joza, Rickert and Kaiserman reported on changes in TSNA levels in Canadian cigarettes from 1970 to 1999, the period

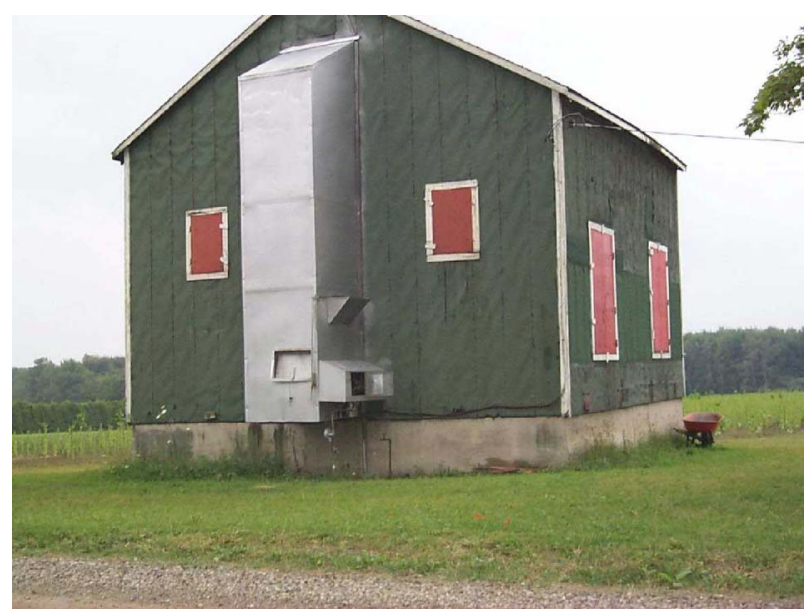

Figure 3 A downdraught kiln with an external natural gas burner. when curing by direct heating was becoming more popular. They found that the quantity of TSNAs in mainstream smoke was relatively constant over time. However, the amount of total particulate matter (TPM) decreased over time, so the average ratio of $\mathrm{NNK}(\mathrm{ng})$ to $\mathrm{TPM}(\mathrm{mg})$ increased from 2.05 to 5.34 from 1970 to 1999. A similar increase in this ratio over the same time period was noted for a popular USA cigarette brand, Marlboro. The authors cautioned that only three Canadian brands and one American brand were investigated in this study. Cigarettes had been stored in a freezer in their original packaging for up to 30 years. They stated that the storage effect may possibly explain some or all of the results obtained. ${ }^{9}$

\section{TOBACCO CURING PRACTICES IN THE 21ST CENTURY}

In the USA, Gentry and his coworkers identified direct heating as the source of oxides of nitrogen and, by further reaction, high levels of TSNAs in tobacco smoke. ${ }^{14}$ They also developed a solution to the problem, a return to indirect heating through the use of heat exchangers.

Heat exchangers are not new technology. In fact, they are old technology and very common. Every home equipped with a forced-air furnace has one. It is the finned device that transfers heat from the combustion chamber to the clean air circulating throughout the home. In a properly functioning home furnace, the combustion gases are never mixed with the warmed air in the house. Only the heat is transferred from the combustion chamber through the heat exchanger. Using heat exchangers in tobacco kilns meant making the kilns work like a home furnace, instead of like an unventilated fire burning indoors. The flues of

Table 1 TSNA sampling from various commercially producing barns, measured in 1999

\begin{tabular}{|c|c|c|c|c|}
\hline $\begin{array}{l}\text { Barn type/ } \\
\text { fuel }\end{array}$ & $\begin{array}{l}\text { Burner } \\
\text { configuration }\end{array}$ & $\begin{array}{l}\text { Period when this } \\
\text { curing process } \\
\text { was widespread }\end{array}$ & $\begin{array}{l}\text { Number } \\
\text { of } \\
\text { samples }\end{array}$ & $\begin{array}{l}\text { TSNA in } \\
\text { tobacco } \\
\text { (ppm) }\end{array}$ \\
\hline Stick/wood & Flues & 1970s and earlier & 6 & 0.3 \\
\hline Bulk/diesel & Heat exchange & 21st century & 27 & 1.0 \\
\hline $\begin{array}{l}\text { Bulk/LPG } \\
\text { (Turkey) }\end{array}$ & Heat exchange & 21st century & 23 & ND \\
\hline Stick/LPG & Direct fired & 1970 s to 1980 s & 1 & 5.9 \\
\hline Bulk/LPG & Direct fired & 1980 s to 1990 s & 43 & 11.0 \\
\hline
\end{tabular}

This table is adapted from table 3 in Exhibit $40368 .^{14}$

LPG, Liquefied petroleum gas; ND, not detected; ppm, parts per million; TSNA, tobacco-specific nitrosamines. 
old were heat exchangers too, albeit less efficient at heat exchanging than the finned heat exchangers.

Dr Gentry's employer, RJ Reynolds, sought public relations benefit from their 'new' policy of requiring indirect heating through heat exchangers for tobacco curing. They issued a news release promoting the finding, claiming that reducing TSNAs was a demand of their 'product stewardship philosophy'. ${ }^{16}$ However, the product stewardship philosophy had been absent in the 1960s and the 1970s when changes in curing methods favoured by the tobacco industry increased the levels of TSNAs.

There were parallel developments in Canada. In 2000, a team of researchers at Imperial Tobacco identified direct heating as a source of oxides of nitrogen and, ultimately, TSNAs. They also proposed heat exchangers as a solution. ${ }^{17}$ In Canada, however, the tobacco industry went beyond just seeking public relations credit for reducing TSNAs. They wanted public money to assist with kiln conversion. They found a willing ally in Bob Speller, the Member of Parliament for Haldimand-Norfolk-Brant, a tobacco farming constituency. In a Tobacco Update letter to his constituents in 2000, Mr. Speller described the tobacco industry as 'proactive' and 'responsible'. ${ }^{18} \mathrm{He}$ also made it clear that he would be seeking public subsidies to help defray the estimated \$C100 million cost of retrofitting kilns with heat exchangers.

Eventually, the cost of kiln conversion was borne by the tobacco farmers, the tobacco companies and the government of the Canadian province of Ontario. The provincial government contributed \$C20 million of public funds to help the tobacco companies correct their earlier abandonment of flue curing. ${ }^{19}$ Although pressure was brought to bear on the federal government to contribute money to kiln conversion, it refused to do so. ${ }^{20}$

\section{Health consequences of changes in levels of TSNAs}

Since direct heating was introduced, the risk of death from smoking has steadily increased. ${ }^{21}$ Michael Thun and his coworkers attributed these increased risks, in part, to changes in cigarette technology that have occurred since the 1960s. However, in addition to increased levels of TSNAs, there were several other changes in cigarette design that would also be part of the explanation for the observed increased risk of death from smoking. Nevertheless, increased levels of TSNAs cannot be ruled out as part of the explanation for the observed increased risk of death from smoking from the 1960s to 2010.

It might be argued that Thun et al's observations of increased risk of death from smoking were observations made in the USA that do not apply to Canada because of substantial differences in the composition of tobacco smoke in the two countries. A closer examination of this possibility is warranted.

There are certainly differences in the composition of tobacco smoke in the two countries. Canadian cigarettes are made of $100 \%$ flue-cured tobacco, while American cigarettes are a blend of flue-cured tobacco and various other tobaccos, including aircured burley tobacco, Oriental tobacco and some others. Burley tobacco is higher in TSNAs and TSNA precursors, which would lead to higher levels of TSNAs in the smoke from American cigarettes. $^{22}$

Measurements made in 2000 and 2001 confirmed that Canadian cigarettes had lower levels of TSNAs than American cigarettes. Canadian cigarettes, however, had higher levels of other carcinogens, including benzo[a]pyrene, cadmium, catechol, phenols and cresols. ${ }^{23}{ }^{24}$ Even though, as noted earlier, the NNK (ng)-TPM (mg) ratio increased from about two to about five in both Canada and the USA, the absolute levels of
TSNAs in Canadian cigarettes have always been lower than American levels of TSNA.

It has been shown that men are at a more advanced stage of the tobacco epidemic than women in both Canada and the USA. ${ }^{25}$ That is, men started smoking earlier, quit smoking in large numbers earlier, and are now benefiting from decreasing rates of death from lung cancer and other diseases earlier than women.

At the same time, there has been a shift in histological types of smoking-caused lung cancer from squamous cell and smallcell carcinomas to adenocarcinoma. This shift has been attributed to changes in cigarette design. ${ }^{21} 2324$ The result of these two simultaneous forces in the 1980s and 1990s has been declines in incidence rates of squamous cell and small-cell carcinomas among both American and Canadian men, while increases in incidence rates for women for these two histological types slowed from the 1980s to the 1990s. As for adenocarcinoma, male rates increased in the 1980s and stabilised in the 1990s, with stabilisation occurring a few years earlier in Canada than in the USA. Among women, incidence rates of adenocarcinoma continue to increase in both countries. ${ }^{23}{ }^{24}$ Overall, these trends reflect smoking cessation by large numbers of women at a later time than men. They also indicate that the changes in cigarettes design that have been attributed to higher rates of adenocarcinoma ${ }^{23} 24$ and increased risks of death for smokers ${ }^{21}$ apply to both Canada and the USA.

While trend lines in lung cancer rates by histological type are moving in approximately parallel fashion in Canada and the USA, rates of adenocarcinoma are consistently higher in the USA than in Canada for both sexes and at every time period. This observation is consistent with the higher levels of TSNAs in American cigarettes. TSNAs are known to be inducers of adenocarcinomas. ${ }^{24}$

It is important to note that, even though the overall rates of death from lung cancer have decreased, due largely to widespread smoking cessation, the risk of death to continuing smokers actually increased, and this increase has been attributed largely to changes in cigarette design and possibly cigarette curing methods that have occurred in both countries. ${ }^{21} 2324$

\section{DISCUSSION}

Cigarettes are inherently dangerous. A tobacco industry scientific consultant, FJC Roe, correctly observed in 1986, 'In the case of carcinogens, smoke contains not just one carcinogen but a galaxy of them'. ${ }^{26}$ With such a 'galaxy' of carcinogens in tobacco smoke, it not surprising that changes in TSNA levels do not result in observable reductions in disease.

Tobacco industry scientist Dr Gentry stated in testimony:

$$
\begin{aligned}
& \text { A-Our conclusion at the end of all of the testing that we did } \\
& \text { was that the reduction in TSNAs did not reduce the toxicity of } \\
& \text { the products. }
\end{aligned}
$$

In Canada, Robert Parker of the Canadian Tobacco Manufacturers' Council said something similar, and also invoked the precautionary principle as a reason for lowering the levels anyway.

There's no evidence low [nitrosamine] levels in tobacco produce less of a health risk....But it's possible to reduce it so it's prudent to do so. ${ }^{28}$

Witness Robert Robitaille also invoked the precautionary principle as a reason for lowering nitrosamines in tobacco: 
Q-Okay. You did mention earlier that the process of asking for conversion of the curing process was the right thing to do; can you expand on that and tell me why it was the right thing to do?

A-Well, as a simple engineer, I mean, we see something that is dangerous, so our role is to make sure that we remove it. So that...in this case, we have this chemical that was identified that was a direct relationship with something that we have an impact on that we could do, so it was the right thing to do. ${ }^{29}$

\section{CONCLUSION}

There were increases in the risk of death for smokers that occurred from the 1970 s to the present. During this period there were design changes in cigarettes and changes in curing practices that resulted in higher levels of TSNAs in tobacco. It is not clear, however, which of these changes are more or less responsible for these increased risks of death.

Another clear pattern that emerges from the study of the history of TSNAs in tobacco smoke is a pattern of the tobacco industry failing to consider possible effects on human health of changes in tobacco curing practices.

- Before the switch from indirect heating flue curing to directfired curing in the 1960s and 1970s, tobacco companies failed to study the effects of their products on human health, and they failed to warn consumers of these dangers. However, it was known at the time that tobacco smoke contained carcinogens, including TSNAs.

- When tobacco companies caused farmers to switch to directfired curing, they failed to monitor chemical changes with possible adverse effects on human health that might occur as a result of blowing furnace exhaust gases directly on curing tobacco leaves. Having failed to monitor these changes, they also failed to warn consumers of the changes that did occur. Consumers were exposed to needlessly higher levels of TSNAs for decades.

- Around the year 2000, when tobacco companies did eventually notice that levels of TSNAs were high and did take steps to lower them, they sought both public relations and monetary credit for doing so, despite the fact that it was tobacco industry-encouraged changes in curing practices that raised the levels of TSNAs in the first place.

- The tobacco companies practised selective application of the precautionary principle. In the 1960s and 1970s, the tobacco companies failed to apply this principle. They changed curing practices that resulted in increasing levels of TSNAs from a low level to a higher level, but did so without consideration of possible effects on human health. When in the 21st century, they lowered TSNA levels from high levels they had previously created to lower (but still non-zero levels), they claimed they were applying the precautionary principle. ${ }^{27-29}$ Not applying the precautionary principle at all in one period, and only partially in another, does not add up to proper precautionary protection of consumers.

In 2014, perhaps with 20/20 hindsight, the US Surgeon General observed

Finally, the rise in the risk of adenocarcinoma of the lung from smoking was unanticipated. This experience, like that of cigarettes with purportedly low yields of toxicants, indicates that changes to cigarettes should undergo careful, evidence-based assessments as such changes are being considered. ${ }^{23}$

Tobacco companies have never provided and still do not provide 'careful, evidence-based assessments' of proposed changes to their products, not the least of which were first increases and then later decreases in the levels of TSNAs in tobacco smoke.

\section{What this paper adds}

Many previously undisclosed documents were made public during a recent class-action trial of tobacco companies in Montreal. From these documents and other related records, it has been shown that changes in tobacco curing practices 40 50 years ago raised the relative levels of tobacco-specific nitrosamines (TSNAs) in tobacco smoke, something the tobacco companies knew or ought to have known, but never revealed. In the 21st century, tobacco companies have once again changed curing practices to lower TSNAs. Since it was tobacco industry action that raised TSNA levels in the first place half a century ago, their claims for credit for their recent action ring hollow indeed.

Funding This research was conducted as part of a project supported by the Quebec Ministry of Health and Social Services.

Competing interests None declared.

Provenance and peer review Not commissioned; externally peer reviewed.

Data sharing statement All the documents and data referred to in this report are available for review.

\section{REFERENCES}

1 Riordan B. Létourneau C. JTI-MacDonald Corp. Case numbers 500-06-000070-983 and 500-06-000076-980. Judgment. Montreal. 2015 (cited 201511 30). http:// citoyens.soquii.qc.ca/php/decision.php?ID=5C56225E67C1EF7C8C5398D9A9A5361B\& page $=1$

2 World Health Organization. International agency for research on cancer. IARC Monographs on the Evaluation of Carcinogenic Risks to Humans. Vol 83. Lyon: Tobacco Smoke and Involuntary Smoking, 2004.

3 Class actions against the tobacco industry: database of plaintiffs' counsel (cited 201412 15). https://tobacco.asp.visard.ca/Main.htm

4 Truth Tobacco Industry Documents. Canadian Tobacco Industry. Castonguay A. L'évolution des caractéristiques physiques, chimiques et toxicologiques des cigarettes canadiennes. Expert report. 2005. Exhibit 1385 (cited 201603 12). https://industrydocuments.library.ucsf.edu/tobacco/docs/mygb0223

5 Truth Tobacco Industry Documents. Canadian Tobacco Industry. SURGEON GENERAL (U.S. Government), U.S. DEPARTMENT OF HEALTH, EDUCATION AND WELFARE. Smoking and health: a Report of the Surgeon General. 1979. Exhibit 601-1979, pdf p. 712 (cited 201603 08). https://industrydocuments.library.ucsf. edu/tobacco/docs/ppxb0223

6 Green C. Truth Tobacco Industry Documents. Control of Tobacco Nitrates and Nitrosamines. 29 October 1982 (cited 201603 12). https://industrydocuments. library.ucsf.edu/tobacco/docs/jgnc0048

7 Truth Tobacco Industry Documents. Canadian Tobacco Industry. Photograph of Coal Fired Kiln Barn. 1956. Exhibit 40367 (cited 201603 08). https://industrydocuments. library.ucsf.edu/tobacco/docs/xnlg0223

8 Truth Tobacco Industry Documents. Canadian Tobacco Industry. Imperial Tobacco Company of Canada Limited How fine Canadian tobacco is grown, matured and made into cigarettes. 1959. Exhibit 1622. p.15 (cited 201603 08). https:/l industrydocuments. library.ucsf.edu/tobacco/docs/kpmg0223

9 Joza P, Rickert B, Kaiserman M. Changes in the TSNA content of Canadian cigarette filler, mainstream and sidestream tobacco smoke: 1970-1999. Presentation: 54th Tobacco Science Research Conference; September 2000. Nashville, Tennessee.

10 Truth Tobacco Industry Documents. Canadian Tobacco Industry. Agriculture Canada. Curing flue-cured tobacco. 1969. Exhibit 1621. pp. 8-12 (cited 201603 08). https://industrydocuments. library.ucsf.edu/tobacco/docs/mxmg0223

11 Class actions against the tobacco industry: database of plaintiffs' counsel. Testimony of Steven Chapman. 21 October 2013, p. 10, Question 5. [Online] (cited 201502 18). https://tobacco.asp.visard.ca/Document.htm?idlist=12\&record= 19849921124916671039

12 Class actions against the tobacco industry: database of plaintiffs' counsel. Testimony of Steven Chapman. 23 October 2013, p. 23, Questions 44-46 (cited 201501 06). 
https://tobacco.asp.visard.ca/Document.htm?idlist=2\&record=198499271249166 71099

13 Truth Tobacco Industry Documents. Canadian Tobacco Industry. Curriculum Vitae of Jeffery Scott Gentry. 2013. Exhibit 40353 (cited 201603 08). https:// industrydocuments.library.ucsf.edu/tobacco/docs/kmlg0223

14 Peele DM, Riddick MG, Edwards ME, et al, Truth Tobacco Industry Documents. Canadian Tobacco Industry. Formation of tobacco-specific nitrosamines in flue-cured tobacco. 1999. Exhibit 40368 (cited 201603 08). https://industrydocuments.library. ucsf.edu/tobacco/docs/pnlg0223

15 Class actions against the tobacco industry: database of plaintiffs' counsel. Testimony of Jeffery Gentry, 7 November 2013, p.45, Q. 154 (cited 201501 07). https:// tobacco.asp.visard.ca/Document.htm?idlist=15\&record=19849996124916671789

16 Truth Tobacco Industry Documents. Canadian Tobacco Industry. News release. R.J. Reynolds to Present Research on Potential Method to Reduce Controversial Compounds in Flue-cured Tobacco. 1999. Exhibit 40369 (cited 201603 09) https://industrydocuments.library.ucsf.edu/tobacco/docs/qnlg0223

17 Morin A, et al. Truth Tobacco Industry Documents. Canadian Tobacco Industry. Relationship Between Tobacco-Specific Nitrosamines (TSNA) and Microbial Populations from Ontario-Grown Tobacco Flue-Cured Under Direct and Indirect Heating. 2000. Exhibit 20187 (cited 201603 09). https://industrydocuments.library. ucsf.edu/tobacco/docs/tilg0223

18 Truth Tobacco Industry Documents. Canadian Tobacco Industry. Speller B. Release of the House of Commons- Tobacco Update. December 19, 2000. Exhibit 21057 (cited 201603 09). https://industrydocuments.library.ucsf.edu/tobacco/docs/ ftng0223

19 Class actions against the tobacco industry: database of plaintiffs' counsel. Testimony of Robert Robitaille, 19 December 2013, p. 133, Q. 314 (cited 201501 07). https://tobacco.asp.visard.ca/Document.htm? idlist=18\&record $=19840831124916680139$

20 Truth Tobacco Industry Documents. Canadian Tobacco Industry. Letter from DA Dodge to GJ Gilvesy. 18 December 2000. Exhibit 21058 (cited 201603 09). https://industrydocuments.library.ucsf.edu/tobacco/docs/gtng0223
21 Thun MJ, et al. Class actions against the tobacco industry: database of plaintiffs' counsel. 2013. 50-year trends in smoking-related mortality in the United States. Exhibit 1718 (cited 201603 09). https://tobacco.asp.visard.ca/Document.htm? idlist=1\&record $=19852171124916703539$

22 Gunduz I, Kondylis A, Jaccard G, et al. Tobacco-specific N-nitrosamines NNN and NNK levels in cigarette brands between 2000 and 2014. Regul Toxicol Pharmacol 2016;76:113-20.

23 Truth Tobacco Industry Documents. Canadian Tobacco Industry. The Health Consequences of Smoking 50 Years of Progress: a Report of the Surgeon General. 2014. Exhibit 601-2014B, pp. 155-186 (pdf pp. 187-219) (cited 201603 09). https://industrydocuments. library.ucsf.edu/tobacco/docs/ tzwh0223

24 Devesa S, Bray F, Vizciano A, et al. International lung cancer trends by histologic type: male: female differences diminishing and adenocarcinoma rate rising. Int J Cancer 2005;117:294-9.

25 Lopez A, Collishaw N, Piha T. A descriptive model of the cigarette epidemic in developed countries. Tob Control 1994;3:242-7.

26 Truth Tobacco Industry Documents. FJC Roe, comments on Preject EMN. 21 July 1986 (cited 201603 08). https://industrydocuments. library.ucsf.edu/tobacco/docs/ zmbn0197

27 Class actions against the tobacco industry: database of plaintiffs' counsel. Testimony of Jeffery Gentry, 7 November 2013, p.149, Q. 543 (cited 19 February 2015). https://tobacco.asp.visard.ca/Document.htm?idlist=20\&record= 19849996124916671789

28 Truth Tobacco Industry Documents. Canadian Tobacco Industry. Tillsonburg Independent. Kiln change won't necessarily make smoking healthier say tobacco-manufacturers. 19 February 2001. Exhibit 1674 (cited 201603 09). https:// industrydocuments.library.ucsf.edu/tobacco/docs/rsng0223

29 Class actions against the tobacco industry: database of plaintiffs' counsel. Testimony of Robert Robitaille, 19 December 2013, pp. 104-105, Q. 209 (cited 19 February 2015). https://tobacco.asp.visard.ca/Document.htm?idlist=18\&record= 19840831124916680139 